九州大学学術情報リポジトリ

Kyushu University Institutional Repository

\title{
Study on Management of Korean Cultivated Mountain Jinseng in Forest
}

Lee, Chang Heon

Faculty of Forest Science, Chonbuk National University

Kang, Hag Mo

Kyeonggi-do Forest Environment Research Station

Choi, Soo Im

Korea Forest Research Institute

Sato, Noriko

Laboratory of Forest Policy, Division of Forest Environment and Management Sciences,

Department of Forest and Forest Products Sciences, Faculty of Agriculture, Kyushu University

https://doi.org/10.5109/17822

出版情報: 九州大学大学院農学研究院紀要. 55 (1)，pp.191-202，2010-02-26. Faculty of Agriculture, Kyushu University

バージョン：

権利関係 : 


\title{
Study on Management of Korean Cultivated Mountain Jinseng in Forest
}

\author{
Chang Heon $\mathrm{LEE}^{1}$, Hag Mo KANG ${ }^{2}$, Soo Im $\mathrm{CHOI}^{3 *}$ \\ and Noriko SATO
}

\author{
Laboratory of Forest Policy, Division of Forest Environment and Management Sciences, \\ Department of Forest and Forest Products Sciences, Faculty of Agriculture, \\ Kyushu University, Fukuoka 812-8581, Japan \\ (Received October 30, 2009 and accepted November 19, 2009)
}

\begin{abstract}
Although the cultivated mountain ginseng is recognized as a highly profitable crop recently and its cultivation area increases largely, there are also several challenges such as authenticity of the cultivated mountain ginseng, absence of certification system through production history of the cultivated mountain ginseng, price lowering by overproduction, and lack of processed goods. The government determines detailed promotion plans including propagation of clean cultivated mountain ginseng production technology, expansion of cultivated mountain ginseng production history system, financial support for production, and establishment of legal basis for fostering the cultivated mountain ginseng. Studies concerned with management of the cultivated mountain ginseng, are limitation factors in making the cultivated mountain ginseng a resource, economic analysis, improvement direction of forest policies, production state and tasks in Jinan-gun, but there are not many management case studies by regions. Therefore, this study performed a survey to seek problems in cultivation and management of the cultivated mountain ginseng and its developmental direction on farms in Kyeonggi-do and Jeollabuk-do. It was resulted that in Kyeonggi-do and Jeollabuk-do, income from the cultivated mountain ginseng accounted for 38\% and 34\% of average gross income of each farm, so the economic contribution of cultivated mountain ginseng to the cultivation farms were large. However, it was also found that quite a number of subjects were not confident of authenticity of seeds and seedlings of cultivated mountain ginseng which they sowed and planted by themselves and that there were many challenges such as theft damage, lack of economic support required for its cultivation and management, passive lease of national and public forest, frustrated introduction of cultivated mountain ginseng certification system, and insufficient market, so it was concluded that preparation of solution for these challenges were needed.
\end{abstract}

\section{INTRODUCTION}

The cultivated mountain ginseng, which is wild ginseng sown and cultivated in the forest, has been cultivated by some farms since 3-40 years ago (Ministry of Agriculture and Forestry, 2007), but its cultivation area increases largely due to recent recognition as a highly profitable crop. It was found that as of the end of 2005 , its cultivation area was 1,620 ha, the number of its cultivators was 1,208, and it production amount and value were 22,493 kg and 12 billion KRW (Korea Forest Service, 2006a; Korea Forest Service, 2006b) (Table 1).

According to its annual production state, it was found that the production amount and value of cultivated mountain ginseng in 2002 was $429 \mathrm{~kg}$ and 0.5 billion KRW, but they increased largely to $75,613 \mathrm{~kg}$ and 159.6 billion KRW respectively (Table 2 ).

It was found that the production amount by regions was greater in order of Chungnam, Cungbuk, Kangwon, and Jeonbuk and that Chungnam accounted for $74 \%$ of total production amount, but accounted for 36\% of total production value with 5.7 billion KRW. However, it was suggested that the production value per kg was 210 thousand KRW in national average, but displayed large differ-

\footnotetext{
1 Faculty of Forest Science, Chonbuk National University, Chonju, 561-756, Korea

Kyeonggi-do Forest Environment Research Station, Osan, 447-290, Korea

Korea Forest Research Institute, Seoul, 130-712, Korea

* Corresponding author (E-mail: csi9626@forest.go.kr)
}

ence by regions. For instance, while Kyeonggi recorded 3,330 thousand KRW, Jeonbuk recorded 1,640 thousand KRW, and Kyeongnam recorded 1,110 thousand KRW, Chungbuk and Chungnam recorded 100 and 40 thousand KRW respectively, which were much lower levels than the national average (Table 3 ).

Besides, it was suggested that the cultivation and production and cultivated mountain ginseng had various challenges including authenticity of cultivated mountain ginseng, introduction of certification system via production history, price lowering by overproduction, lack of processed goods, and theft damage. Accordingly, the government determines 2008 detailed promotion plans including propagation of clean cultivated mountain ginseng production technology (including agricultural chemical use standard, etc.), expansion of cultivated mountain ginseng production history system ( 4 cites, 0.2 billion KRW), financial support for its production ( 0.5 billion $\mathrm{KRW}$ ), establishment of legal basis for fostering the cultivated mountain ginseng, regulation and public relations for preventing illegal distribution of Chinese cultivated mountain ginseng (Korea Forest Service, 2008). Concerned with management of the cultivated mountain ginseng, there are studies on limitation factors and economic analysis in making the cultivated mountain ginseng a resource (Chang, 2002), improvement direction of forest policies (Han, 2002), production state and tasks in Jinan-gun (Muju-Gun, 2008) until now, but there are not many studies on management case by regions.

Therefore, it is the purpose of this study to seek 
Table 1. Cultivation state of cultivated mountain ginseng by regions (as of the end of 2005)

\begin{tabular}{|c|c|c|c|c|c|c|c|c|c|}
\hline Classification & Total & $\begin{array}{l}\text { Kyeongbuk } \\
\text { Province }\end{array}$ & $\begin{array}{l}\text { Jeonbuk } \\
\text { Province }\end{array}$ & $\begin{array}{l}\text { Kangwon } \\
\text { Province }\end{array}$ & $\begin{array}{c}\text { Chungnam } \\
\text { Province }\end{array}$ & $\begin{array}{l}\text { Chungbuk } \\
\text { Province }\end{array}$ & $\begin{array}{c}\text { Kyeongnam } \\
\text { Province }\end{array}$ & $\begin{array}{l}\text { Jeonnam } \\
\text { Province }\end{array}$ & $\begin{array}{l}\text { Kyeonggi } \\
\text { Province }\end{array}$ \\
\hline $\begin{array}{l}\text { Cultivation } \\
\text { area } \\
\text { (ha) }\end{array}$ & $\begin{array}{l}1,620 \\
(100)\end{array}$ & $\begin{array}{l}492 \\
(30)\end{array}$ & $\begin{array}{l}411 \\
(25)\end{array}$ & $\begin{array}{l}318 \\
(20)\end{array}$ & $\begin{array}{l}163 \\
(10)\end{array}$ & $\begin{array}{l}81 \\
(5)\end{array}$ & $\begin{array}{l}79 \\
(5)\end{array}$ & $\begin{array}{l}46 \\
(3)\end{array}$ & $\begin{array}{l}30 \\
(2)\end{array}$ \\
\hline $\begin{array}{c}\text { Cultivator } \\
\text { (person) }\end{array}$ & $\begin{array}{l}1,208 \\
(100)\end{array}$ & $\begin{array}{l}32 \\
(3)\end{array}$ & $\begin{array}{l}147 \\
(12)\end{array}$ & $\begin{array}{l}336 \\
(28)\end{array}$ & $\begin{array}{l}70 \\
(6)\end{array}$ & $\begin{array}{l}354 \\
(29)\end{array}$ & $\begin{array}{l}224 \\
(18)\end{array}$ & $\begin{array}{l}44 \\
(4)\end{array}$ & 1 \\
\hline $\begin{array}{c}\text { Production } \\
\text { amount } \\
(\mathrm{kg})\end{array}$ & $\begin{array}{c}22,493 \\
(100)\end{array}$ & 408 & $\begin{array}{c}2,740 \\
(12)\end{array}$ & $\begin{array}{c}17,386 \\
(77)\end{array}$ & 340 & $\begin{array}{c}1,500 \\
(7)\end{array}$ & 69 & - & 50 \\
\hline $\begin{array}{c}\text { Income } \\
\text { (100 million } \\
\text { KRW })\end{array}$ & $\begin{array}{l}120.0 \\
(100)\end{array}$ & 14.2 & $\begin{array}{l}43.0 \\
(36)\end{array}$ & $\begin{array}{l}42.6 \\
(36)\end{array}$ & 10.7 & 1.8 & 5.2 & - & 2.5 \\
\hline
\end{tabular}

Note: The value in ( ) is the component ratio.

Source: Korea Forest Service. 2006. Guide to cultivate the cultivated mountain ginseng.

Table 2. Production state of cultivated mountain ginseng by year (as of 2006)

\begin{tabular}{cccc}
\hline Classification & $\begin{array}{c}\text { Amount } \\
(\mathrm{kg})\end{array}$ & $\begin{array}{c}\text { Total value } \\
(100 \text { million KRW })\end{array}$ & $\begin{array}{c}\text { Value/kg } \\
(10 \text { thousand KRW })\end{array}$ \\
\hline 2002 & 429 & 5 & 117 \\
2003 & 679 & 7 & 103 \\
2004 & 3,233 & 22 & 68 \\
2005 & 9,764 & 117 & 120 \\
2006 & 75,613 & 159 & 21 \\
\hline
\end{tabular}

Source: Korea Forest Service. 2007. Statistical Yearbook of Forestry.

Table 3. Production state of cultivated mountain ginseng by region (as of 2006)

\begin{tabular}{|c|c|c|c|c|c|c|c|c|c|}
\hline Classification & Total & $\begin{array}{c}\text { Chungnam } \\
\text { Province }\end{array}$ & $\begin{array}{l}\text { Chungbuk } \\
\text { Province }\end{array}$ & $\begin{array}{l}\text { Kangwon } \\
\text { Province }\end{array}$ & $\begin{array}{l}\text { Jeonbuk } \\
\text { Province }\end{array}$ & $\begin{array}{c}\text { Kyeongbuk } \\
\text { Province }\end{array}$ & $\begin{array}{l}\text { Jeonnam } \\
\text { Province }\end{array}$ & $\begin{array}{l}\text { Kyeonggi } \\
\text { Province }\end{array}$ & $\begin{array}{c}\text { Kyeongnam } \\
\text { Province }\end{array}$ \\
\hline $\begin{array}{l}\text { Amount } \\
(\mathrm{kg})\end{array}$ & $\begin{array}{c}75,613 \\
(100)\end{array}$ & $\begin{array}{c}54,667 \\
(72)\end{array}$ & $\begin{array}{c}10,000 \\
(13)\end{array}$ & $\begin{array}{c}6,143 \\
(8)\end{array}$ & $\begin{array}{c}2,808 \\
(4)\end{array}$ & $\begin{array}{l}1,430 \\
(2)\end{array}$ & 370 & 150 & 45 \\
\hline $\begin{array}{c}\text { Value } \\
\text { (100 million } \\
\text { KRW) }\end{array}$ & $\begin{array}{c}159 \\
(100)\end{array}$ & $\begin{array}{c}57 \\
(36)\end{array}$ & $\begin{array}{c}4 \\
(3)\end{array}$ & $\begin{array}{c}33 \\
(21)\end{array}$ & $\begin{array}{c}46 \\
(29)\end{array}$ & $\begin{array}{l}10 \\
(6)\end{array}$ & 4 & 5 & 0.5 \\
\hline $\begin{array}{c}\text { Value/kg } \\
\text { (10 thousand } \\
\text { KRW) }\end{array}$ & 21 & 10 & 4 & 54 & 164 & 70 & 108 & 333 & 111 \\
\hline
\end{tabular}

Note: The value in ( ) is the component ratio.

Source: Korea Forest Service. 2007. Statistical Yearbook of Forestry.

problems in cultivation and management of the cultivated mountain ginseng and its developmental direction in future via positive survey.

\section{MATERIALS AND METHODS}

For 15 farms and 4 commodity units in Yangpyeonggun, Gapyeong-gun, Kwangju-city and Namyangju-city Kyeonggi-do and 34 farms in Jinan-gun and Muju gun in Jeollabuk-do, a survey was performed. This survey was performed through personal interview over 3 months from early April to early June, 2008 and its contents include reproduction structure such as labor composition, managing farm land state, forest management state, cultivation scale, production state, selling, and distribution state of the cultivated mountain ginseng. The survey data were analyzed by regions, ages, scales of managing farm land, scales of forest management, and scales of cultivation. 


\section{RESULTS AND DISCUSSIONS}

Cultivation and production state of cultivated mountain ginseng in the investigated siteds

Kyeonggi-do

According to the investigation results on the sites such as Yangpyeong-gun, Gapyeong-gun, Kwangju-city, and Namyangju-city it was found that there were total 73 farms including 43 farms cultivating the cultivated mountain ginseng in Yangpyeong-gun, 14 farms in Gapyeong-gun, 15 farms in Kwangju-city, and 1 farm in Namyangju-city. However, according to opinion, the number of total farms cultivating the cultivated mountain ginseng in Kyeonggi-do was presumed about 100. As there are many farms which participate in cultivating the cultivated mountain ginseng or grow it negatively, it is actual circumstance that the relevant local community cannot grasp the number of cultivation farms, their cultivation area, and production amount accurately.

\section{Jeollabuk-do}

According to the investigation results on the sites such as Jinan-gun and Muju-gun, it was found that the number of farms supported by assistant project of Jinangun such as corporations, commodity units, and personal farms was total 427 including 13 in 2003, 23 in 2004, 27 in 2005, 188 in 2006, 137 in 2007, and 43 in 2008 and that the project amount was total 668.2 ha as of 2008 starting from 15 ha in 2003. Total supported value in 2003-2008 was 4.45 billion KRW ( 0.75 billion KRW of national expense, 1.11 billion KRW of province expense, 0.83 billion KRW of district expense, and 1.76 billion KRW of own expense) and it seems that the projection record can be obtained from 2012 because of cultivation term of the cultivated mountain ginseng (Jinan-gun, 2008). In case of Muju-gun, it was found that the number of cultivation farms and cultivation area were 45 and 100 ha respectively and the projection record was $200 \mathrm{~kg}$, but they increased 49 farms and 140 ha (Muju-gun, 2008).

\section{Case study of farms growing the cultivated moun- tain ginseng}

Reproduction structure of cultivation farm: Labor composition

In 49 households subjected to the survey, total number of household members over 20 years old was 105 persons and average number of household members per household was 2.1. In case of Kyeonggi-do, average number of household members and average age of household head were 2.1 and 50 years old and they were 2.1 and 49 years old respectively in Jeollabuk-do. By age classes, in case of Kyeonggi-do, 40's and 50's accounted for the largest portion as 31\% and 25\% respectively and in case of Jeollabuk-do, also 40's and 50's were the most as 38\% and 26\%. Namely, the people in 40's and 50's took the most ratios in labor composition of the cultivated mountain ginseng cultivation.

Reproduction structure of cultivation farm: Scale of managing farm land

Total managing farm land including paddy and dry fields of households in Kyeonggi-do was 28.1 ha and average scale of managing farmland by households was 1.9 ha, but the households less than 1.0 ha accounted for 8 . In

Table 4. Composition of household labor

(Unit: person)

\begin{tabular}{|c|c|c|c|c|c|c|c|c|}
\hline Classification & Total & household & 20's & 30's & 40's & 50's & 60's & Over 70's \\
\hline $\begin{array}{l}\text { Total } \\
(49)\end{array}$ & $\begin{array}{c}105 \\
(100)\end{array}$ & 2.1 & 10 & 13 & $\begin{array}{c}29 \\
(28)\end{array}$ & $\begin{array}{c}36 \\
(34)\end{array}$ & 8 & 9 \\
\hline $\begin{array}{l}\text { Kyeonggi-do } \\
\text { (15) }\end{array}$ & $\begin{array}{c}32 \\
(100)\end{array}$ & 2.1 & 2 & 6 & $\begin{array}{c}10 \\
(31)\end{array}$ & $\begin{array}{c}8 \\
(25)\end{array}$ & 4 & 2 \\
\hline $\begin{array}{l}\text { Jeollabuk -do } \\
\qquad(34)\end{array}$ & $\begin{array}{c}73 \\
(100)\end{array}$ & 2.1 & 8 & 7 & $\begin{array}{c}19 \\
(26)\end{array}$ & $\begin{array}{c}28 \\
(38)\end{array}$ & 4 & 7 \\
\hline
\end{tabular}

Note: 1. People under 20 years old were excluded the total of household members.

2. The value in ( ) is the component ratio (\%).

3. Value in ( ) of the above classification is number of households (\%).

Table 5. Scale of managing farm land

\begin{tabular}{|c|c|c|c|c|c|c|}
\hline Classification & Total & ha/household & under 1.0 ha & 1.0-2.0ha & 2.0-3.0ha & over 3.0 ha \\
\hline $\begin{array}{l}\text { Total } \\
(49)\end{array}$ & 100.4 & 2.0 & $\begin{array}{l}8.5 \\
(19)\end{array}$ & $\begin{array}{c}13.2 \\
(9)\end{array}$ & $\begin{array}{l}25.1 \\
(11)\end{array}$ & $\begin{array}{l}53.6 \\
(10)\end{array}$ \\
\hline $\begin{array}{l}\text { Kyeonggi-do } \\
\text { (15) }\end{array}$ & 28.1 & 1.9 & $\begin{array}{l}4.1 \\
(8)\end{array}$ & $\begin{array}{l}1.5 \\
(1)\end{array}$ & $\begin{array}{l}4.2 \\
(2)\end{array}$ & $\begin{array}{l}18.3 \\
(4)\end{array}$ \\
\hline $\begin{array}{c}\text { Jeollabuk -do } \\
\qquad(34)\end{array}$ & 72.3 & 2.1 & $\begin{array}{c}4.4 \\
(11)\end{array}$ & $\begin{array}{c}11.7 \\
(8)\end{array}$ & $\begin{array}{c}20.9 \\
(9)\end{array}$ & $\begin{array}{c}35.3 \\
(6)\end{array}$ \\
\hline
\end{tabular}

Note: The value in ( ) is the number of households. 
Jeollabuk-do, the total managing farm land was 72.3 ha and the average scale of managing farmland by households was 2.1 ha, similar value with that of Kyeonggi-do. Reproduction structure of cultivation farm: Forest management state

Total scale of forest management of the 15 households in Kyeonggi-do was 69 ha and its average per household was 46.3 ha. The total scale of forest management of the 34 households in Jeollabuk-do was 463.3 ha and its average per household was 13.6 ha. It was suggested that Kyeoggi-do had over 3 times larger average scale of forest management per household than that of Jeollabuk-do (Table 6).

Besides, for forest commencement and production state, it was found that Kyeonggi-do conducted 10.3 ha of work commencement such as planting fruit trees and Jeollabuk-do did 31.9 ha of work commencement such as thining. For forest production, it was found that Kyeonggi-do had 42,800 thousand KRW of income from nuts such as chestnuts and pine nuts and Jeollabuk-do had 56,000 thousand KRW of income from fruits such as persimmon and mushrooms (Table 7).

Reproduction structure of cultivation farm: Land transfer of farm and forest

For buying and selling state of farmland and forest land, it was found that in case of Kyeonggi-do, purchase of farmland and forest land by succession and donation accounted for $56 \%$ and $51 \%$ and that although most selling of both farmland and forest land were made in 2000's, the purchasing was more than selling for both farmland and forest land. Similarly, in case of Jellabuk-do, the purchase of farmland and forest land by succession and donation accounted for $51 \%$ and $59 \%$ and that although most selling of both farmland and forest land were made in 2000's, the purchasing was more than selling for both farmland and forest land. The reason that the purchasing was more than selling seems that in both regions, the average age of household head was about 50 years old,

Table 6. Scale of forest management

\begin{tabular}{|c|c|c|c|c|c|}
\hline Classification & Total & household average & below 5.0ha & 5.0-10.0ha & Over 10.0ha \\
\hline $\begin{array}{l}\text { Total } \\
(49)\end{array}$ & $1,158.3$ & 23.6 & $\begin{array}{l}39.9 \\
(17)\end{array}$ & $\begin{array}{l}85.0 \\
(13)\end{array}$ & $\begin{array}{c}969.2 \\
(19)\end{array}$ \\
\hline $\begin{array}{l}\text { Kyeonggi-do } \\
\text { (15) }\end{array}$ & 695.0 & 46.3 & $\begin{array}{l}7.1 \\
(5)\end{array}$ & $\begin{array}{l}31.0 \\
(5)\end{array}$ & $\begin{array}{c}592.7 \\
(5)\end{array}$ \\
\hline $\begin{array}{l}\text { Jeollabuk -do } \\
\text { (34) }\end{array}$ & 463.3 & 13.6 & $\begin{array}{l}32.8 \\
(12)\end{array}$ & $\begin{array}{c}54.0 \\
(8)\end{array}$ & $\begin{array}{c}376.5 \\
(14)\end{array}$ \\
\hline
\end{tabular}

Note: The value in $($ ) is the number of households.

Table 7. Forest commencement and production state (during recent 5 years)

\begin{tabular}{|c|c|c|c|c|c|c|c|c|c|c|c|c|c|c|}
\hline \multirow[b]{2}{*}{ Classification } & & & \multicolumn{8}{|c|}{ Commencement (ha) } & \multicolumn{4}{|c|}{$\begin{array}{c}\text { Production } \\
\text { (10 thousand KRW) }\end{array}$} \\
\hline & & & Total & Thinning & $\begin{array}{c}\text { Fruit } \\
\text { tree } \\
\text { planting }\end{array}$ & $\begin{array}{l}\text { Special } \\
\text { crop } \\
\text { planting }\end{array}$ & $\begin{array}{l}\text { Natural } \\
\text { forest } \\
\text { fostering }\end{array}$ & $\begin{array}{c}\text { Forest } \\
\text { road } \\
(\mathrm{km})\end{array}$ & $\begin{array}{c}\text { Forestation } \\
\text { of material } \\
\text { trees }\end{array}$ & $\begin{array}{c}\text { Clear } \\
\text { cutting }\end{array}$ & Total & Fruits & $\begin{array}{l}\text { Materials } \\
\text { from clear } \\
\text { cutting }\end{array}$ & Mushroom \\
\hline \multirow{4}{*}{ Kyeonggi-do } & \multirow{4}{*}{$\begin{array}{c}\text { By scales } \\
\text { of forest } \\
\text { management }\end{array}$} & $\begin{array}{l}\text { Total } \\
(15)\end{array}$ & 10.3 & - & 2.3 & 8.0 & - & - & - & - & 4,280 & 4,280 & - & - \\
\hline & & $\begin{array}{c}\text { Below 5.0ha } \\
\text { (5) }\end{array}$ & - & - & - & - & - & - & - & - & - & - & - & - \\
\hline & & $\begin{array}{c}5.0-10.0 \mathrm{ha} \\
\text { (5) }\end{array}$ & 3.3 & - & 2.3 & 1.0 & - & - & - & - & 4,280 & 4,280 & - & - \\
\hline & & $\begin{array}{l}\text { Over 10.0ha } \\
\text { (5) }\end{array}$ & 7.0 & - & - & 7.0 & - & - & - & - & - & - & - & - \\
\hline \multirow{4}{*}{ Jeollabuk -do } & \multirow{4}{*}{$\begin{array}{c}\text { By scales } \\
\text { of forest } \\
\text { management }\end{array}$} & $\begin{array}{l}\text { Total } \\
(34)\end{array}$ & 31.9 & 26.2 & - & - & 1.7 & 1.4 & 1.5 & 2.5 & 5,600 & 2,470 & 330 & 2,800 \\
\hline & & $\begin{array}{l}\text { Below 5.0ha } \\
\text { (12) }\end{array}$ & 3.0 & 1.3 & - & - & 1.7 & 0.5 & - & - & 3,270 & 2,470 & - & 800 \\
\hline & & $\begin{array}{c}5.0-10.0 \mathrm{ha} \\
\text { (8) }\end{array}$ & 12.7 & 11.7 & - & - & - & 0.9 & - & 1.0 & 2,130 & - & 130 & 2,000 \\
\hline & & $\begin{array}{l}\text { Over 10.0ha } \\
\text { (14) }\end{array}$ & 16.2 & 13.2 & - & - & - & - & 1.5 & 1.5 & 200 & - & 200 & - \\
\hline
\end{tabular}

Note: 1 . Value in ( ) is number of households.

2. Forest roads are excluded from the total. 
so it was done for stabilization of future living base and increase of family income through expansion of farmland and forest land (Table 8).

Reproduction structure of cultivation farm:Family gross income state

In case of 8 households with income from the cultivated mountain ginseng among the 15 households, subjects in Kyeonggi-do, it was found that average gross income of 6 households excluding 2 house holds with 2.5 billion and 0.32 billion KRW of income from the cultivated mountain ginseng was 61.67 million KRW. Among them, the income from cultivated mountain ginseng was 23.25 million KRW and accounted for 38\%, the highest ratio. By factors and classes, it was found that farms with higher age had larger average gross income per household and income from the cultivated mountain ginseng. However, by scales of managing farm land, it was found that the cultivated mountain ginseng in the class below 1.0 ha accounted for 38\%, consistent forest work in the class between 1.0-2.0 ha accounted for 47\%, and agriculture in the class over 3.0 ha accounted for $35 \%$. By scales of forest management, it was found that consistent forest work in the class below 5.0 ha was $50 \%$, the highest and that in the 1st generation in the class between 5.010.0 ha, the cultivated mountain ginseng took the entire of family gross income, but in the 3rd generation in the class over 10.0 ha, ratio of business owner was the highest. By cultivation scales of cultivated mountain ginseng, it was found in other classes excluding the class between 3.0-5.0 ha, business owner and consistent forest work accounted for $33 \%$ and $44 \%$, the highest ratio, respectively.

For the family gross income of 7 households with no sales experience of the cultivated mountain ginseng, it was found that the average gross income was 76.79 million KRW and the ratio was higher in order of others (ginseng etc) 40\%, consistent forest work 19\%, and livestock industry 15\%. There was not large difference between classes in the scale of forest management and cultivation of the cultivated mountain ginseng. Besides, the reason that the households with income from the cultivated mountain ginseng had less average gross income per household than that of households without its sales experience was that the 2nd generation of ginseng growing farm had large gross income from ginseng sales. It seems that when active yield and sales of farms with income from the cultivated mountain ginseng are expanded, their family income will increase also (Table 9).

Besides, in case of Jellabuk-do, average gross income of 16 households with income from the cultivated mountain ginseng among 34 households was 68.34 million KRW. Among them, the income from cultivated mountain ginseng was 22.97 million KRW and accounted for 34\%, the highest ratio in total family gross income. By factors and classes, it was found that the class in higher age had less average gross income and income from the cultivated mountain ginseng, but in the class in 30's, the cultivated mountain ginseng and in the class in 40-50's, agriculture accounted for the highest. Average gross income by managing farmland scales was the largest in the class of 1.0$2.0 \mathrm{ha}$, and income from the cultivated mountain ginseng was the largest in the class of 2.0-3.0 ha. By forest possession scales, it was found that the class with larger scale had more average gross income and income from the cultivated mountain ginseng, and by cultivation scales of the cultivated mountain ginseng, it was shown that the class with larger scale had more average gross income and income from the cultivated mountain ginseng also.

For family gross income of 18 households without sales experience of the cultivated mountain ginseng, their average gross income was 56.13 million won and the order of higher ratio was agriculture $57 \%$, own business $31 \%$, and livestock industry 5\%. For reference, the whole average farm incomes in Kyeonggi-do and Jeollabuk-do in 2007 were 43.13 million KRW and 29.51 million KRW respectively and nationwide average worker's family income was 44.11 million (Ministry of Food, Agriculture,

Table 8. Land transfer of farm and forest (Unit: ha)

\begin{tabular}{|c|c|c|c|c|c|c|c|}
\hline \multirow{2}{*}{\multicolumn{2}{|c|}{ Classification }} & \multicolumn{3}{|c|}{ Buying } & \multicolumn{3}{|c|}{ Selling } \\
\hline & & \multirow{2}{*}{$\begin{array}{l}\text { Total } \\
50.9\end{array}$} & \multirow{2}{*}{$\begin{array}{l}\text { Farmland } \\
\text { 11.1(100) }\end{array}$} & \multirow{2}{*}{$\begin{array}{c}\text { Forest land } \\
39.8(100)\end{array}$} & \multirow{2}{*}{$\frac{\text { Total }}{3.5}$} & \multirow{2}{*}{$\begin{array}{c}\text { Farmland } \\
1.2\end{array}$} & \multirow{2}{*}{$\begin{array}{c}\text { Forest land } \\
2.3\end{array}$} \\
\hline & Total (15) & & & & & & \\
\hline & $\begin{array}{c}\text { Succession and } \\
\text { donation }\end{array}$ & 26.6 & $6.2(56)$ & $20.4(51)$ & - & - & - \\
\hline \multirow[t]{5}{*}{ Kyeonggi-do } & Before 1980's & 0.3 & 0.3 & - & - & - & - \\
\hline & 1990's & 15.1 & 0.7 & $14.4(36)$ & 0.3 & 0.3 & - \\
\hline & 2000's & 8.9 & $3.9(35)$ & 5.0 & 3.2 & 0.9 & 2.3 \\
\hline & Total (34) & 239.6 & $70.0(100)$ & $169.6(100)$ & 24.7 & 1.7 & 23.0 \\
\hline & $\begin{array}{c}\text { Succession and } \\
\text { donation }\end{array}$ & 135.6 & $35.5(51)$ & $100.1(59)$ & - & - & - \\
\hline \multirow[t]{4}{*}{ Jeollabuk -do } & Before 1980's & 1.4 & 1.4 & - & - & - & - \\
\hline & 1980's & 9.3 & 6.8 & 2.5 & - & - & - \\
\hline & 1990's & 33.1 & $14.1(20)$ & 19.0 & 0.4 & 0.4 & - \\
\hline & 2000's & 60.2 & $12.2(17)$ & $48.0(28)$ & 24.3 & 1.3 & 23.0 \\
\hline
\end{tabular}

Note: 1 . The value in ( ) in the above classification is the number of households.

2. The value in $($ ) is the component ratio. 
Table 9. Family gross income state (Kyeonggi-do)

(Unit: 10 thousand KRW)

\begin{tabular}{|c|c|c|c|c|c|c|c|c|c|c|c|}
\hline \multicolumn{2}{|c|}{ Classification } & $\begin{array}{c}\text { Total/ } \\
\text { household }\end{array}$ & Total & $\begin{array}{c}\text { Cultivated } \\
\text { mountain ginseng/ } \\
\text { household }\end{array}$ & $\begin{array}{l}\text { Cultivated } \\
\text { mountain } \\
\text { ginseng }\end{array}$ & $\begin{array}{l}\text { Consistent } \\
\text { forest work }\end{array}$ & $\begin{array}{c}\text { Business } \\
\text { owner }\end{array}$ & Forestry & Livestock & $\begin{array}{l}\text { Transient } \\
\text { forest } \\
\text { work }\end{array}$ & Others \\
\hline \multicolumn{2}{|c|}{$\begin{array}{l}\text { Total } \\
(6)\end{array}$} & 6,167 & $\begin{array}{c}37,002 \\
(100) \\
\end{array}$ & 2,325 & $\begin{array}{c}13,950 \\
(38)\end{array}$ & $\begin{array}{c}5,800 \\
(16)\end{array}$ & 5,400 & 3,500 & 2,800 & 2,700 & 2,852 \\
\hline \multirow{3}{*}{ By ages } & $\begin{array}{l}30 \text { 's } \\
(1)\end{array}$ & 3,442 & $\begin{array}{l}3,442 \\
(100)\end{array}$ & 150 & $\begin{array}{l}150 \\
(4)\end{array}$ & $\begin{array}{c}3,000 \\
(87)\end{array}$ & - & - & - & - & 292 \\
\hline & $\begin{array}{l}40 \text { 's } \\
(2)\end{array}$ & 4,150 & $\begin{array}{l}8,300 \\
(100)\end{array}$ & 1,250 & $\begin{array}{c}2,500 \\
(30)\end{array}$ & $\begin{array}{c}2,800 \\
(34)\end{array}$ & - & - & 1,000 & 2,000 & - \\
\hline & $\begin{array}{l}50 \text { 's } \\
\text { (3) }\end{array}$ & 8,420 & $\begin{array}{c}25,260 \\
(100)\end{array}$ & 3,767 & $\begin{array}{c}11,300 \\
(45)\end{array}$ & - & $\begin{array}{c}5,400 \\
(21)\end{array}$ & 3,500 & 1,800 & 700 & 2,560 \\
\hline \multirow{3}{*}{ By farms } & $\begin{array}{c}\text { below } 1.0 \text { ha } \\
\text { (4) }\end{array}$ & 7,411 & $\begin{array}{c}29,642 \\
(100)\end{array}$ & 3,163 & $\begin{array}{c}12,650 \\
(43)\end{array}$ & 4,000 & $\begin{array}{l}5,400 \\
(18)\end{array}$ & 3,000 & 1,000 & 2,000 & 1,592 \\
\hline & $\begin{array}{l}1.0-2.0 \text { ha } \\
\text { (1) }\end{array}$ & 3,800 & $\begin{array}{l}3,800 \\
(100)\end{array}$ & 1,000 & $\begin{array}{c}1,000 \\
(26)\end{array}$ & $\begin{array}{c}1,800 \\
(47)\end{array}$ & - & - & 1,000 & - & - \\
\hline & $\begin{array}{l}\text { over } 3.0 \text { ha } \\
\text { (1) }\end{array}$ & 3,560 & $\begin{array}{l}3,560 \\
(100)\end{array}$ & 300 & $\begin{array}{l}300 \\
(8)\end{array}$ & - & - & 500 & 800 & 700 & $\begin{array}{c}1,260 \\
(35)\end{array}$ \\
\hline \multirow{3}{*}{ By forests } & $\begin{array}{c}\text { below } 5.0 \text { ha } \\
\text { (2) }\end{array}$ & 3,971 & $\begin{array}{l}7,942 \\
(100)\end{array}$ & 825 & $\begin{array}{l}1,650 \\
(21)\end{array}$ & $\begin{array}{l}4,000 \\
(50)\end{array}$ & - & - & - & 2,000 & 292 \\
\hline & $\begin{array}{c}5.0-10.0 \text { ha } \\
\text { (1) }\end{array}$ & 10,000 & $\begin{array}{c}10,000 \\
(100)\end{array}$ & 10,000 & $\begin{array}{c}10,000 \\
(100)\end{array}$ & - & - & - & - & - & - \\
\hline & $\begin{array}{c}\text { over } 10.0 \text { ha } \\
\text { (3) }\end{array}$ & 6,353 & $\begin{array}{c}19,060 \\
(100)\end{array}$ & 767 & $\begin{array}{c}2,300 \\
(12)\end{array}$ & 1,800 & $\begin{array}{c}5,400 \\
(28)\end{array}$ & $\begin{array}{c}3,500 \\
(18)\end{array}$ & 2,800 & 700 & 2,560 \\
\hline \multirow{3}{*}{$\begin{array}{l}\text { By } \\
\text { cultivated } \\
\text { mountain } \\
\text { ginsen }\end{array}$} & $\begin{array}{c}\text { Below } 1.0 \text { ha } \\
\text { (2) }\end{array}$ & 8,100 & $\begin{array}{c}16,200 \\
(100)\end{array}$ & 1,250 & $\begin{array}{c}2,500 \\
(15)\end{array}$ & 1,000 & $\begin{array}{c}5,400 \\
(33)\end{array}$ & $\begin{array}{c}3,000 \\
(19)\end{array}$ & 1,000 & 2,000 & 1,300 \\
\hline & $\begin{array}{c}1.0-3.0 \text { ha } \\
\text { (3) }\end{array}$ & 3,601 & $\begin{array}{c}10,802 \\
(100)\end{array}$ & 483 & $\begin{array}{c}1,450 \\
(13)\end{array}$ & $\begin{array}{c}4,800 \\
(44)\end{array}$ & - & 500 & 1,800 & 700 & 1,552 \\
\hline & $\begin{array}{l}3.0-5.0 \text { ha } \\
\text { (1) }\end{array}$ & 10,000 & $\begin{array}{c}10,000 \\
(100)\end{array}$ & 10,000 & $\begin{array}{c}10,000 \\
(100)\end{array}$ & - & - & - & - & - & - \\
\hline
\end{tabular}

Note: 1 . Value in ( ) of the above classification is number of households (\%).

2. The value in ( ) is the component ratio (\%).

3. By farmland is by managing farmland scales, by forest is by forest management scales, and by the cultivated mountain ginseng isby cultivated mountain ginseng scale.

Forestry, and Fisheres, 2008) (Table 10).

Reproduction structure of cultivation farm: Agroforestry management future planing

Additionally, for future main family economy, it was suggested that 15 households in Kyeonggi-do answered as 6 of own business, 3 of agriculture, and 3 of cultivated mountain ginseng orderly, and for managing farm land scale, 10 households answered maintenance of status quo and 5 households among them answered expansion, but most of households planning expansion were the classes in 30 and 40's and answered that it was for stabilization of living base. For forest management scale, it was suggested that they consisted of 12 of expansion, 3 of quo status maintenance, and 1 of reduction, wherein 9 household of the 12 households answered that it would be done for cultivation of the cultivated mountain ginseng. In case of Jeollabuk-do, it was resulted that for future main family economy, 25 households answered agriculture and 4 households answered the cultivated mountain ginseng and that for the managing farmland scale, their answers consisted of 20 households of quo status maintenance and 12 households of expansion, wherein the reason for the expansion was increase of family income. For the forest management scale, it was shown that their answers included 17 households of expansion and 16 households of quo status maintenance and they answered that the reason of expansion was for increase of income by 8 households and for expansion of the cultivated mountain ginseng by 7 households.

Cultivation, sales and distribution state of the cultivated mountain ginseng: Cultivation scale of the cultivated mountain ginseng and its planting forest

For cultivation scale of the cultivated mountain ginseng, it was found in case of Kyeonggi-do that while the average cultivation area per household was 19.6 ha, the cultivation area of 3 households in the class with over 5.0 ha was 94 ha and the average cultivation area of the remaining 12 households excluding the above 3 households was 1.0 ha. In case of Jeollabuk-do, it was found that while the average cultivation area per household was 7.0 ha, the cultivation area of 8 households in the class with over 5.0 ha was 23 ha and the average cultivation area of the remaining 26 households excluding the above 8 households was 2.1 ha. Besides, in case of Kyeonggi-do, the cultivation area of cultivated mountain ginseng accounted for $36 \%$ of total forest management 
Table 10. Family gross income state (Jeollabuk-do)

(Unit: 10 thousand KRW)

\begin{tabular}{|c|c|c|c|c|c|c|c|c|c|c|c|}
\hline \multicolumn{2}{|c|}{ Classification } & $\begin{array}{c}\text { Total/ } \\
\text { household }\end{array}$ & Total & $\begin{array}{c}\text { Cultivated } \\
\text { mountain ginseng/ } \\
\text { household }\end{array}$ & Agriculture & $\begin{array}{l}\text { Cultivated } \\
\text { mountain } \\
\text { ginseng }\end{array}$ & $\begin{array}{l}\text { Business } \\
\text { owner }\end{array}$ & $\begin{array}{l}\text { Consistent } \\
\text { forest } \\
\text { work }\end{array}$ & Forestry & Livestock & Others \\
\hline \multicolumn{2}{|c|}{$\begin{array}{l}\text { Total } \\
(16)\end{array}$} & 6,834 & $\begin{array}{c}109,337 \\
(100)\end{array}$ & 2,297 & $\begin{array}{c}38,000 \\
(35)\end{array}$ & $\begin{array}{c}36,757 \\
(34) \\
\end{array}$ & $\begin{array}{c}11,500 \\
(11)\end{array}$ & 8,480 & 6,000 & 2,300 & 5,200 \\
\hline \multirow{3}{*}{ By ages } & $\begin{array}{l}30 \text { 's } \\
(3)\end{array}$ & 9,347 & $\begin{array}{c}28,040 \\
(100)\end{array}$ & 7,500 & 1,500 & $\begin{array}{c}22,500 \\
(80)\end{array}$ & 3,500 & 240 & - & - & - \\
\hline & $\begin{array}{l}40 \text { 's } \\
(6)\end{array}$ & 9,073 & $\begin{array}{c}54,440 \\
(100)\end{array}$ & 1,333 & $\begin{array}{c}26,000 \\
(48)\end{array}$ & $\begin{array}{c}8,000 \\
(15)\end{array}$ & 7,200 & $\begin{array}{c}8,240 \\
(15)\end{array}$ & 5,000 & - & - \\
\hline & $\begin{array}{l}50 \text { 's } \\
(7)\end{array}$ & 3,837 & $\begin{array}{c}26,857 \\
(100)\end{array}$ & 894 & $\begin{array}{c}10,500 \\
(39)\end{array}$ & $\begin{array}{c}6,257 \\
(23)\end{array}$ & 800 & - & 1,000 & 2,300 & 5,200 \\
\hline \multirow{4}{*}{ By farms } & $\begin{array}{c}\text { below } 1.0 \text { ha } \\
\text { (3) }\end{array}$ & 4,533 & $\begin{array}{c}13,600 \\
(100)\end{array}$ & 3,267 & 2,000 & $\begin{array}{l}9,800 \\
(72)\end{array}$ & 1,000 & - & - & - & - \\
\hline & $\begin{array}{c}1.0-2.0 \mathrm{ha} \\
(6)\end{array}$ & 8,205 & $\begin{array}{c}49,227 \\
(100)\end{array}$ & 1,405 & $\begin{array}{c}17,800 \\
(36)\end{array}$ & $\begin{array}{c}8,427 \\
(17)\end{array}$ & 8,000 & 8,000 & 6,000 & 800 & 200 \\
\hline & $\begin{array}{c}2.0-3.0 \text { ha } \\
(5)\end{array}$ & 7,428 & $\begin{array}{c}37,140 \\
(100)\end{array}$ & 3,620 & $\begin{array}{c}13,500 \\
(36)\end{array}$ & $\begin{array}{c}18,100 \\
(49)\end{array}$ & 2,500 & 240 & - & 1,500 & 1,000 \\
\hline & $\begin{array}{c}\text { over } 3.0 \text { ha } \\
\text { (2) }\end{array}$ & 4,685 & $\begin{array}{l}9,370 \\
(100)\end{array}$ & 215 & $\begin{array}{c}4,700 \\
(50)\end{array}$ & $\begin{array}{l}430 \\
(5)\end{array}$ & - & 240 & - & - & $\begin{array}{c}4,000 \\
(43) \\
\end{array}$ \\
\hline \multirow{3}{*}{ By forests } & $\begin{array}{c}\text { below } 5.0 \text { ha } \\
\text { (3) }\end{array}$ & 2,660 & $\begin{array}{l}7,980 \\
(100)\end{array}$ & 400 & $\begin{array}{c}2,700 \\
(34)\end{array}$ & $\begin{array}{c}1,200 \\
(15)\end{array}$ & $\begin{array}{c}2,500 \\
(31)\end{array}$ & 480 & - & - & - \\
\hline & $\begin{array}{c}5.0-10.0 \text { ha } \\
\text { (3) }\end{array}$ & 5,442 & $\begin{array}{c}16,327 \\
(100)\end{array}$ & 509 & $\begin{array}{c}13,000 \\
(80)\end{array}$ & $\begin{array}{c}1,527 \\
(9)\end{array}$ & - & - & 1,000 & 800 & - \\
\hline & $\begin{array}{l}\text { over } 10.0 \text { ha } \\
\text { (10) }\end{array}$ & 8,503 & $\begin{array}{c}85,030 \\
(100)\end{array}$ & 3,403 & $\begin{array}{c}22,300 \\
(26)\end{array}$ & $\begin{array}{c}34,030 \\
(40)\end{array}$ & 9,000 & 8,000 & 5,000 & 1,500 & 5,200 \\
\hline \multirow{4}{*}{$\begin{array}{c}\text { By } \\
\text { cultivated } \\
\text { mountain } \\
\text { ginseng }\end{array}$} & $\begin{array}{c}\text { Below } 1.0 \text { ha } \\
\text { (1) }\end{array}$ & 1,100 & $\begin{array}{l}1,100 \\
(100)\end{array}$ & 300 & - & $\begin{array}{l}300 \\
(27)\end{array}$ & - & - & - & - & - \\
\hline & $\begin{array}{c}1.0-3.0 \text { ha } \\
\text { (2) }\end{array}$ & 5,665 & $\begin{array}{c}11,330 \\
(100)\end{array}$ & 515 & $\begin{array}{c}5,500 \\
(97)\end{array}$ & $\begin{array}{c}1,030 \\
(9)\end{array}$ & - & - & - & 800 & 4,000 \\
\hline & $\begin{array}{c}3.0-5.0 \text { ha } \\
(7)\end{array}$ & 7,130 & $\begin{array}{c}49,907 \\
(100)\end{array}$ & 561 & $\begin{array}{c}27,700 \\
(56)\end{array}$ & $\begin{array}{c}3,927 \\
(8)\end{array}$ & 3,300 & $\begin{array}{c}8,480 \\
(17)\end{array}$ & 6,000 & - & 200 \\
\hline & $\begin{array}{c}\text { Over } 5.0 \text { ha } \\
(6)\end{array}$ & 7,833 & $\begin{array}{l}47,000 \\
(100)\end{array}$ & 5,250 & $\begin{array}{l}4,800 \\
(10)\end{array}$ & $\begin{array}{c}31,500 \\
(67)\end{array}$ & $\begin{array}{c}8,200 \\
(17)\end{array}$ & - & - & 1,500 & 1,000 \\
\hline
\end{tabular}

Note: 1. Value in ( ) of the above classification is number of households (\%).

2. The value in ( ) is the component ratio (\%).

3. By farmland is by managing farmland scales, by forest is by forest management scales, and by the cultivated mountain ginseng is by cultivated mountain ginseng scale.

Table 11. Agroforestry management future planning (Unit: household )

\begin{tabular}{|c|c|c|c|c|c|c|c|c|c|c|c|c|c|c|}
\hline \multirow[b]{2}{*}{ Classification } & \multicolumn{7}{|c|}{ Main family economy } & \multicolumn{3}{|c|}{ Scale of managing farmland } & \multicolumn{4}{|c|}{ Forest management scale } \\
\hline & Total & Agriculture & Livestock & $\begin{array}{c}\text { Cultivated } \\
\text { mountain } \\
\text { ginseng }\end{array}$ & Forestry & $\begin{array}{l}\text { Business } \\
\text { owner }\end{array}$ & $\begin{array}{c}\text { Transient } \\
\text { forest } \\
\text { work }\end{array}$ & Expansion & $\begin{array}{l}\text { Maintenance } \\
\text { of quo status }\end{array}$ & Reductio & Total & Expansion & $\begin{array}{l}\text { Maintenance } \\
\text { of quo status }\end{array}$ & Reduction \\
\hline Total & 49 & 28 & 2 & 7 & 3 & 8 & 1 & 17 & 30 & 2 & 49 & 29 & 18 & 2 \\
\hline $\begin{array}{c}\text { Kyeonggi-do } \\
\text { (15) }\end{array}$ & 15 & 3 & 1 & 3 & 1 & 6 & 1 & 5 & 10 & - & 15 & 12 & 2 & 1 \\
\hline $\begin{array}{c}\text { Jeollabuk-do } \\
\text { (34) }\end{array}$ & 34 & 25 & 1 & 4 & 2 & 2 & - & 12 & 20 & 2 & 34 & 17 & 16 & 1 \\
\hline
\end{tabular}

Note: The value in ( ) is the number of households.

area, but individually owned forest was only $6 \%$ of the forest management area. In case of Jeollabuk-do, the cultivation area of cultivated mountain ginseng accounted for $51 \%$ of total forest management area, but individually owned forest was $37 \%$ of the forest management area (Table 12).

In addition, although the optimal land for the cultivated mountain ginseng was a land over $500 \mathrm{~m}$ above sea 
Table 12. Cultivation scale state of the cultivated mountain ginseng

(Unit: ha, \%)

\begin{tabular}{|c|c|c|c|c|c|c|c|}
\hline Classification & Total & $\begin{array}{l}\text { household } \\
\text { average }\end{array}$ & $\begin{array}{l}\text { Cultivated mountain } \\
\text { ginseng/forest }\end{array}$ & $\begin{array}{l}\text { below } \\
1.0 \text { ha }\end{array}$ & $1.0-3.0 \mathrm{ha}$ & $3.0-5.0 \mathrm{~h} \mathrm{a}$ & $\begin{array}{l}\text { below } \\
5.0 \text { ha }\end{array}$ \\
\hline $\begin{array}{l}\text { Total } \\
(49)\end{array}$ & 531.5 & 10.8 & 45.9 & $\begin{array}{l}4.9 \\
(12)\end{array}$ & $\begin{array}{l}22.3 \\
(14)\end{array}$ & $\begin{array}{l}38.3 \\
(12)\end{array}$ & $\begin{array}{c}466.0 \\
(11)\end{array}$ \\
\hline $\begin{array}{c}\text { Kyeonggi-do } \\
\text { (15) }\end{array}$ & 294.7 & 19.6 & 35.9 & $\begin{array}{l}2.4 \\
(8)\end{array}$ & $\begin{array}{l}4.7 \\
(3)\end{array}$ & $\begin{array}{l}4.3 \\
(1)\end{array}$ & $\begin{array}{c}283.3 \\
(3)\end{array}$ \\
\hline $\begin{array}{c}\text { Jeollabuk -do } \\
\text { (34) }\end{array}$ & 236.8 & 7.0 & 51.1 & $\begin{array}{l}2.5 \\
(4)\end{array}$ & $\begin{array}{l}17.6 \\
(11)\end{array}$ & $\begin{array}{l}34.0 \\
(11)\end{array}$ & $\begin{array}{c}182.7 \\
(8)\end{array}$ \\
\hline
\end{tabular}

Note: The value in ( ) is the number of households

Table 13. Forest area Cultivated mountain ginseng

\begin{tabular}{|c|c|c|c|c|c|c|c|c|}
\hline \multicolumn{3}{|c|}{ Classification } & Total & Oak & Larch & $\begin{array}{l}\text { White } \\
\text { pine }\end{array}$ & Pine & $\begin{array}{l}\text { Rigida } \\
\text { pine }\end{array}$ \\
\hline \multirow{5}{*}{ Kyeonggi-do } & \multirow{5}{*}{$\begin{array}{c}\text { By } \\
\text { cultivation } \\
\text { scales of } \\
\text { the } \\
\text { cultivated } \\
\text { mountain } \\
\text { ginseng }\end{array}$} & $\begin{array}{l}\text { Total } \\
\text { (15) }\end{array}$ & $\begin{array}{l}294.7 \\
(100)\end{array}$ & $\begin{array}{c}287.8 \\
(98)\end{array}$ & $\begin{array}{l}1.2 \\
(-)\end{array}$ & $\begin{array}{l}5.7 \\
(2)\end{array}$ & - & - \\
\hline & & $\begin{array}{c}\text { Below } 1.0 \text { ha } \\
\text { (8) }\end{array}$ & 2.4 & 0.5 & 0.2 & 1.7 & - & - \\
\hline & & $\begin{array}{c}1.0-3.0 \text { ha } \\
\text { (3) }\end{array}$ & 4.7 & 1.7 & 1.0 & 2.0 & - & - \\
\hline & & $\begin{array}{l}3.0-5.0 \text { ha } \\
\text { (1) }\end{array}$ & 4.3 & 4.3 & - & - & - & - \\
\hline & & $\begin{array}{l}\text { Over } 5.0 \text { ha } \\
\text { (3) }\end{array}$ & 283.3 & 281.3 & - & 2.0 & - & - \\
\hline \multirow{5}{*}{ Jeollabuk -do } & \multirow{5}{*}{$\begin{array}{c}\text { By } \\
\text { cultivation } \\
\text { scales of } \\
\text { the } \\
\text { cultivated } \\
\text { mountain } \\
\text { ginseng }\end{array}$} & $\begin{array}{l}\text { Total } \\
(34)\end{array}$ & $\begin{array}{l}236.8 \\
(100)\end{array}$ & $\begin{array}{c}180.7 \\
(76)\end{array}$ & $\begin{array}{l}35.2 \\
(15)\end{array}$ & $\begin{array}{l}1.2 \\
(-)\end{array}$ & $\begin{array}{l}5.7 \\
(2)\end{array}$ & $\begin{array}{c}14.0 \\
(6)\end{array}$ \\
\hline & & $\begin{array}{c}\text { Below } 1.0 \text { ha } \\
\text { (4) }\end{array}$ & 2.5 & 1.9 & 0.6 & - & - & - \\
\hline & & $\begin{array}{c}1.0-3.0 \text { ha } \\
\text { (11) }\end{array}$ & 17.6 & 14.3 & 2.3 & - & 1.0 & - \\
\hline & & $\begin{array}{c}3.0-5.0 \text { ha } \\
\text { (11) }\end{array}$ & 34.0 & 26.5 & 4.0 & - & 3.5 & - \\
\hline & & $\begin{array}{l}\text { Over } 5.0 \text { ha } \\
\text { (8) }\end{array}$ & 182.7 & 138.0 & 28.3 & 1.2 & 1.2 & 14.0 \\
\hline
\end{tabular}

Note: 1 . The value in ( ) is the component ratio (\%).

2. Value in ( ) of the above classification is number of households (\%).

where natural shading by natural broadleaf trees is provided and it is easy to provide oxygen and drain water, the forest composition where the cultivated mountain ginseng was planted included 98\% of oak tree in Kyeonggi-do and $76 \%$ of oak tree, $15 \%$ of larch, and $6 \%$ of Rigida pine in Jeollabuk-do.

Cultivation, sales and distribution state of the cultivated mountain ginseng: Forest commencement of the cultivated mountain ginseng and purchase of its seeds and seedling

Forest commencement for cultivating the cultivated mountain ginseng included branch rearing, thinning, and removal of miscellaneous tree and facility establishment included fence, monitoring camera, and warning board. However, all the cultivators did not perform the forest commencement or install facilities and in case of Kyeonggi-do, 6 households planed forest rearing, 2 households plan to remove weeds, and 1 household plan a theft prevention facility. In case of Jeollabuk-do, 7 households planed establishment of fence and monitoring camera in future.

In addition, for the seeds and seedlings for cultivation of cultivated mountain ginseng in Kyeonggi-do, 5 households among the 15 households produced by themselves and 9 households purchased to sow and plant them. In Jeollabuk-do, 23 households among the 34 households produced by themselves and 19 households purchased to sow and plant them. However, the number of cultivator who sowed and planted seeds and seedlings of general ginseng, not of cultivated mountain ginseng was 6 in Kyeonggi-do and 9 in Jeollabuk-do. Not a few of cultivators who purchased seeds and seedlings of cultivated mountain ginseng to sow and plant them from other people did not confirm their authenticity.

Cultivation, sales and distribution state of the cultivated mountain ginseng: Production cost of the culti- 
vated mountain ginseng

Cost required for producing the cultivated mountain ginseng was average 9.76 million KRW a household in Kyeonggi-do, of which contents included $27 \%$ of rent, $22 \%$ of seeds, and $18 \%$ of seedlings. The cost a household in Jeollabuk-do was 34.02 million KRW, which comprised $47 \%$ of labor, $15 \%$ of seeds, and $13 \%$ of seedlings (Table 14).

Cultivation, sales and distribution state of the cultivated mountain ginseng: Sales and distribution of cultivated mountain ginseng

First, the selling price of cultivated mountain ginseng was different by cultivators in both Kyeonggi-do and Jeollabuk-do. In Kyeonggi-do, 5-13 year old cultivated mountain ginseng was sole at 18-100 thousand KRW and in Jeollabuk-do, 5-10 year old cultivated mountain ginseng was sole at 10-30 thousand KRW, so it was shown that its selling price was determined by subjectivity of cultivator without accurate standards. In case of Kyeonggi-do, among 7 households with experience selling cultivated mountain ginseng, 5 households sold them to acquaintances and 2 household sold them to wholesaler and friend, and department store. In case of Jeollabuk-do, among 16 households with experience selling cultivated mountain ginseng, 12 households sold them to their ,acquaintances 2 household to store and friend, and department store, 1 household sold via internet and festival, and 1 household sold using internet.

Cultivation, sales and distribution state of the culti- vated mountain ginseng: Management plan of the cultivated mountain ginseng and difficulties on its cultivation and management

It was found that cultivation career of the cultivated mountain ginseng was average 8 years as $1-25$ years in Kyeonggi-do and it was average 7 years as $2-30$ years in Jeollabuk-do. For future cultivation scale of the cultivated mountain ginseng, 10 households among 15 households in Kyeonggi-do planned expansion for increase of family income, but 5 households answered to maintain quo status on account of difficulties in marketing, risk of theft, and overproduction. In case of Jeollabuk-do, 20 households among 34 households planned expansion on account of increase of family income, high profitability, and making processed goods, but 14 households planned to maintain quo status on account of difficulties in marketing and management, risk of price lowering, and insufficient labor. However, in both regions, there was no plan for reduction.

For contents of support on cultivation of cultivated mountain ginseng, it was found that in Kyeonggi-do, only 1 household among 15 received support from the government and the relevant community and in Jeollabuk-do, 21 households among 34 received support including cost for seeds and seedlings, planting, and facilities such as monitoring camera and fence from the local community. The supported value per household was 9.09 million KRW and were used for planting, purchasing seeds and seedlings, and facility installation orderly.

Table 14. Production cost of cultivated mountain ginseng

(Unit: 10 thousand KRW)

\begin{tabular}{|c|c|c|c|c|c|c|c|c|c|c|c|c|c|c|}
\hline \multicolumn{3}{|c|}{ Classification } & Total & $\begin{array}{l}\text { household } \\
\text { average }\end{array}$ & Rent & Seeds & Seedling & $\begin{array}{l}\text { Warning } \\
\text { board }\end{array}$ & $\begin{array}{c}\text { Labor } \\
\text { cost }\end{array}$ & Fence & $\begin{array}{c}\text { Monitoring } \\
\text { Camera }\end{array}$ & $\begin{array}{c}\text { Forest } \\
\text { road }\end{array}$ & Thinning & Others \\
\hline \multirow{5}{*}{ Kyeonggi-do } & \multirow{5}{*}{$\begin{array}{c}\text { By } \\
\text { cultivation } \\
\text { scales of } \\
\text { the } \\
\text { cultivated } \\
\text { mountain } \\
\text { ginseng }\end{array}$} & $\begin{array}{l}\text { Total } \\
(15)\end{array}$ & $\begin{array}{c}14,640 \\
(100)\end{array}$ & 976 & $\begin{array}{c}3,920 \\
(27)\end{array}$ & $\begin{array}{c}3,160 \\
(22)\end{array}$ & $\begin{array}{c}2,700 \\
(18)\end{array}$ & $\begin{array}{c}2,100 \\
(14)\end{array}$ & $\begin{array}{c}1,400 \\
(10)\end{array}$ & $\begin{array}{l}1,120 \\
(8)\end{array}$ & 240 & - & - & - \\
\hline & & $\begin{array}{l}\text { Below } \\
1.0 \text { ha } \\
(8)\end{array}$ & $\begin{array}{l}6,950 \\
(100)\end{array}$ & 869 & - & $\begin{array}{c}2,370 \\
(34)\end{array}$ & 1,500 & 2,100 & 450 & 530 & - & - & - & - \\
\hline & & $\begin{array}{c}1.0-3.0 \mathrm{ha} \\
\text { (3) }\end{array}$ & $\begin{array}{l}2,100 \\
(100)\end{array}$ & 700 & - & 550 & $\begin{array}{c}1,200 \\
(57)\end{array}$ & - & - & 350 & - & - & - & - \\
\hline & & $\begin{array}{c}\text { 3.0-5.0ha } \\
\text { (1) }\end{array}$ & $\begin{array}{l}1,000 \\
(100)\end{array}$ & 1,000 & - & - & - & - & $\begin{array}{l}850 \\
(85)\end{array}$ & 50 & 100 & - & - & - \\
\hline & & $\begin{array}{c}\text { Over 5.0ha } \\
\text { (3) }\end{array}$ & $\begin{array}{c}520 \\
(100)\end{array}$ & 173 & - & $\begin{array}{l}240 \\
(46)\end{array}$ & - & - & 100 & 40 & 140 & - & - & - \\
\hline \multirow{5}{*}{ Jeollabuk-do } & \multirow{5}{*}{$\begin{array}{c}\text { By } \\
\text { cultivation } \\
\text { scales of } \\
\text { the } \\
\text { cultivated } \\
\text { mountain } \\
\text { ginseng }\end{array}$} & $\begin{array}{l}\text { Total } \\
(34)\end{array}$ & $\begin{array}{c}115,675 \\
(100)\end{array}$ & 3,402 & 323 & $\begin{array}{c}16,876 \\
(15)\end{array}$ & $\begin{array}{c}15,051 \\
(13)\end{array}$ & - & $\begin{array}{c}54,105 \\
(47)\end{array}$ & $\begin{array}{l}1,600 \\
(1)\end{array}$ & 70 & 550 & 100 & $\begin{array}{c}27,000 \\
(23)\end{array}$ \\
\hline & & $\begin{array}{c}\text { Below } \\
1.0 \text { ha } \\
(4)\end{array}$ & $\begin{array}{c}950 \\
(100)\end{array}$ & 238 & - & 65 & - & - & $\begin{array}{l}885 \\
(93)\end{array}$ & - & - & - & - & - \\
\hline & & $\begin{array}{c}\text { 1.0-3.0ha } \\
\text { (11) }\end{array}$ & $\begin{array}{l}7,396 \\
(100)\end{array}$ & 672 & - & 196 & 800 & - & $\begin{array}{c}6,200 \\
(84)\end{array}$ & - & - & 200 & - & - \\
\hline & & $\begin{array}{c}\text { 3.0.-5.0ha } \\
\text { (11) }\end{array}$ & $\begin{array}{c}30,276 \\
(100)\end{array}$ & 2,752 & - & $\begin{array}{c}13,236 \\
(44)\end{array}$ & 4,550 & - & $\begin{array}{c}11,370 \\
(38)\end{array}$ & 600 & 70 & 350 & 100 & - \\
\hline & & $\begin{array}{l}\text { Over 5.0ha } \\
\text { (8) }\end{array}$ & $\begin{array}{l}76,730 \\
(100)\end{array}$ & 9,591 & 323 & 3,379 & $\begin{array}{c}9,701 \\
(13)\end{array}$ & - & $\begin{array}{c}35,650 \\
(46)\end{array}$ & 1,000 & - & - & - & $\begin{array}{c}27,000 \\
(35)\end{array}$ \\
\hline
\end{tabular}

Note: 1 . The value in ( ) is the component ratio (\%).

2. Value in ( ) of the above classification is number of households (\%) 
Besides, it was resulted that for the problems in cultivating the cultivated mountain ginseng, the subjects in Kyeonggi-do answered theft damage, authenticity of the cultivated mountain ginseng in sowing and planting, animal damage such as field mouse, and natural selection and the subjects in Jeollabuk-do answered wild animal damage by field mouse and pheasant, theft damage, authenticity of the cultivated mountain ginseng in sowing and planting, insufficiency of economic support required for its cultivation and administration as larger problems.

For desires on cultivation, they answered lease expansion of national and public forest, introduction of cultivated mountain ginseng certification system, supporting seeds and seedlings of cultivated mountain ginseng, support for facilities such as fence and monitoring camera, guidance of culturing technology in case of Kyeonggi-do. In Jeollabuk-do, there were more desires on support for facilities such as fence and monitoring camera, supporting seeds and seedlings of cultivated mountain ginseng, expansion of market, and introduction of cultivated mountain ginseng certification system. Operation state of cultivated mountain ginseng commodity unit of Kyeonggi-do: A commodity unit

The residents leased 10 ha of private forest in common under conditions of paying $5 \%$ of production volume in 2007 and planted 50 million KRW worth of 2 year old seedling of cultivated mountain ginseng, but most of them died and was left alone. In other case, residents of a village leased in common 5 ha of national forest in 2007 under conditions of paying 0.9 million KRW annually (agreement for 5 years) and planted 33 million KRW worth of ginseng seedlings. At present, although removal of runners and weeding works are performed commonly by residents, the number of farms which actually participate positively was 14 and they had a plan to execute shipment when it would be 8-9 years old. The sown seeds paid by residents in common, and currently, about 30 plants per $\mathrm{m}^{2}$ are alive, but it is prospected that about $40 \%$ of them will remain in harvest period of the $8-9$ year old cultivated mountain ginseng.

Operation state of cultivated mountain ginseng commodity unit of Kyeonggi-do: B commodity unit

Cultivation area of B commodity unit was 17 ha and was being leased and cultivated in common of 15 residents in size of $0.3-5.0$ ha. Administration and production of each cultivation section is performed by each resident. 14 of the 15 residents have formed the cultivation land since 2006 and seeds and seedlings of ginseng used for planting and sowing were $10 \%$ and $90 \%$ respectively. The 15 members of commodity unit shared information on cultivation and marketing and paid facility cost required for administration such as monitoring camera, fence, and shading screen in common considering each cultivation area.

Operation state of cultivated mountain ginseng commodity unit of Kyeonggi-do: C commodity unit

50 village residents leased 20 ha of national forest in common under conditions of paying $10 \%$ of production volume in 2005 and planted cultivated mountain ginseng seedlings in 3.3 ha among them. They answered that they planted cultivated mountain ginseng seedlings by support of relevant local community in 2005, but they didn't sure authenticity of the seedlings. The residents are performing weeding works in common, but didn't install fences for preventing theft. Initially, the residents expected income as much as 200 million won, but expects at present 40 60 million won of income because of theft and natural selection.

Operation state of cultivated mountain ginseng commodity unit of Kyeonggi-do: D commodity unit

48 village residents leased 3 ha of national forest in common in 2003 under conditions of paying 1.4 million KRW annually and planted cultivated mountain ginseng seedlings in 1 ha among them. Seeds and seedlings of ginseng used for planting and sowing were 10\% and 90\% respectively. The relevant local community mediated the lease of national forest and supported cost for seeds, monitoring camera, and fence. However, as well as increase of cultivator of cultivated mountain ginseng and uncertain yield, the cost for administration and lease paid annually became economic burden to the residents without income from the cultivated mountain ginseng, so most residents gave up the cultivation as of 2008 .

\section{CONCLUSION}

1. The average age of household head in Kyeonggi-do and Jeollabuk-do, subject cites, was prime of life as 50 and 49 years old respectively and the average scale of managing farmland was 1.9 ha and 2.1 ha respectively.

2. The average scale of forest management per household in Kyeonggi-do and Jeollabuk-do was 46.3 ha and 13.6 ha respectively. For forest production, it was found that Kyeonggi-do had 42.80 million KRW of income from nuts such as chestnuts and pine nuts and Jeollabuk-do had 56 million KRW of income from fruits such as persimmon and mushrooms.

3. The purchase of farmland and forest land in both region by succession and donation accounted for more than half and purchasing was more than selling.

4. In case of Kyeonggi-do, the average gross income of households with income from the cultivated mountain ginseng was 61.67 million KRW. Among them, the income from the cultivated mountain ginseng accounted for the highest ratio, 38\%, but the average gross income of households without income from the cultivated mountain ginseng was 76.79 million KRW, which comprised $40 \%$ of others (ginseng etc.), $19 \%$ of consistent forest work, $19 \%$ of forestry, and $19 \%$ of livestock industry.

5. In case of Jeollabuk-do, the average gross income of households with income from the cultivated mountain ginseng was 68.34 million KRW. Among them, the income from the cultivated mountain ginseng was 22.97 million KRW and accounted for the highest ratio, 34\%, but the average gross income of households without income from the cultivated mountain ginseng was 56.13 million KRW, which comprised 
$57 \%$ of agriculture, $31 \%$ of own business, and $5 \%$ of livestock industry.

6. In case of Kyeonggi-do that while the average cultivation area per household was 19.6 ha, the cultivation area of 3 households in the class with over 5.0 ha was 94 ha and the average cultivation area of the remaining 12 households excluding the above 3 households was 1.0 ha. In case of Jeollabuk-do, it was found that while the average cultivation area per household was 7.0 ha, the cultivation area of 8 households in the class with over 5.0 ha was 23 ha and the average cultivation area of the remaining 26 households excluding the above 8 households was 2.1 ha.

7. Forest commencement for cultivating the cultivated mountain ginseng included branch rearing, thinning, and removal of miscellaneous tree and facility establishment included fence, monitoring camera, and warning board.

8. However, the number of cultivator who sowed and planted seeds and seedlings of general ginseng, not of cultivated mountain ginseng was 6 in Kyeonggi-do and 9 in Jeollabuk-do. Not a few of cultivators who purchased seeds and seedlings of cultivated mountain ginseng to sow and plant them from other people did not confirm their authenticity.

9. The cost used for producing the cultivated mountain ginseng was average 9.76 million KRW a household in Kyeonggi-do, wherein the cost for lease accounted for the highest ratio, 27\%. In Jeollabuk-do, the cost was average 34.02 million KRW a household, wherein the cost for labor accounted for the highest ratio, $47 \%$.

10. The selling price of cultivated mountain ginseng was different by cultivators in both Kyeonggi-do and Jeollabuk-do. In Kyeonggi-do, 5-13 year old cultivated mountain ginseng was sole at 18-100 thousand KRW and in Jeollabuk-do, 5-10 year old cultivated mountain ginseng was sole at 10-30 thousand KRW, so it was shown that its selling price was determined by subjectivity of cultivator without accurate standards. In both regions, the selling was done via acquaintance and it was suggested that the market was not diverse.

11. The cultivation career of the cultivated mountain ginseng was average 8 years in Kyeonggi-do and it was average 7 years in Jeollabuk-do. For future cultivation scale of the cultivated mountain ginseng, 10 households among 15 households in Kyeonggi-do planned expansion for increase of family income and 20 of 34 households in Jeollabuk-do planned expansion on account of increase of family income, high profitability and making processed goods. However, in both regions, there was no plan for reduction.

12. For contents of support on cultivation of cultivated mountain ginseng, it was found that in Kyeonggi-do, only 1 household among 15 received support from the government and the relevant community and in Jeollabuk-do, 21 households among 34 received support including cost for seeds and seedlings, planting, and facilities such as monitoring camera and fence from the local community. The supported value per household was 9.09 million KRW and were used for planting, purchasing seeds and seedlings, and facility installation orderly.

13. Besides, it was resulted that for the problems in cultivating the cultivated mountain ginseng, the subjects in Kyeonggi-do answered theft damage, authenticity of the cultivated mountain ginseng in sowing and planting, animal damage such as field mouse, and natural selection and the subjects in Jeollabuk-do answered wild animal damage by field mouse and pheasant, theft damage, authenticity of the cultivated mountain ginseng in sowing and planting, insufficiency of economic support required for its cultivation and administration as larger problems.

14. For desires on cultivation, they answered lease expansion of national and public forest, introduction of cultivated mountain ginseng certification system, supporting seeds and seedlings of cultivated mountain ginseng, support for facilities such as fence and monitoring camera, guidance of culturing technology in case of Kyeonggi-do. In Jeollabuk-do, there were more desires on support for facilities such as fence and monitoring camera, supporting seeds and seedlings of cultivated mountain ginseng, expansion of market, and introduction of cultivated mountain ginseng certification system.

15. 2 commodity groups among 4 commodity groups in Kyeonggi-do was operated poorly because of inactive participation of residents and unfavorable feeling from economic burden, but other 2 commodity groups had an expectation on future income due to active participation.

The subjected farms cultivating cultivated mountain ginseng in Kyeonggi-do and Jeollabuk-do sought stabilization of living base and increase of family income through purchase of farmland and forest. In addition, it was suggested that the cultivated mountain ginseng provided large economic contribution and a number of farms planned expansion of its cultivation. Therefore, it seems that following measures should be sought on cultivation and production activities of cultivated mountain ginseng for continuous increase of family income.

1. The cultivated mountain ginseng is largely spotlighted as a forest crop which does not give large damage on forest land and forest trees and has high profitability per unit area and expected by residents suffering from economic difficulties because of not varied income structure to contribute to their family income largely. Accordingly, it is required for positive lease of national and public forest to farms not possessing forest land. This brings new recognition of importance and economic value of forest to general farms as well as forest owners having taken negative attitude in forest management and change to positive attitude on use and management of forest may be expected.

2. It seems that considering joint protection of forest against forest fire and illegal felling having continued 
for long time, when the lease of national and public forest is made performed by commodity group comprising residents, it will be helpful for the entire local economy.

3. Although the cultivated mountain ginseng is sold at relatively high price currently, selling via acquaintances accounts for most of them, so it is needed to explore various sales routes. Additionally, development of various goods such as jelly, granule, extract, soap, and beverage and processing technology is required preparing mass production and price decrease from expansion of cultivation of the cultivated mountain ginseng.

4. Although optimal lands for cultivating the cultivated mountain ginseng was identified by conventional studies, it seems that the cultivation site which is close to the residential area even though there are some disadvantages for cultivation, facilitates prevention of theft and administration to increase the production volume.

5. Finally, there are some cases that the ginseng cultivated from seeds and seedlings of general ginseng are sold as the cultivated mountain ginseng, but it is difficult for customers to judge authenticity of the cultivated mountain ginseng. Therefore, it is urgent to expand introduction of certification system through production history system promoted by the government and it is considered essential to prepare measures to provide seeds and seedlings of the cultivated mountain ginseng systematically.

\section{REFERENCES}

Chang, W. H. 2002 Analysis of limitation factors and economic features of making mountain ginseng resource. Study on Korean Ginseng. 2: 43-58

Han, Y. C. 2002 Improvement direction of forest policy for making mountain ginseng resource. Study on Korean Ginseng. 2: $70-81$

Jinan-gun. 2008 Promotion state of cultivated mountain ginseng cultivation complex

Korea Forest Service. 2006a Method for growing cultivated mountain ginseng

Korea Forest Service. 2006b Scale of mountain ginseng market

Korea Forest Service. 2007 Statistical Yearbook of Forestry

Korea Forest Service. 2008 Detailed promotion plan of major projects in 2008

Lim, J. R. 2001 Production status and challenges of cultivated mountain ginseng in Jinan. Study on Korean Ginseng. 1 25-37

Ministry of Food, Agriculture, Forestry, and Fisheres. 2008 Statistics of Food, Agriculture, Forestry, and Fisheres

Muju-gun. 2008 Cultivation status of cultivated mountain ginseng

Yangpyeong Forestry Cooperative Federation. 2008 Cultivator of cultivated mountain ginseng in Kyeonggi-do 